\title{
Analysis on supply chain finance accounts receivable financing mode game
}

\author{
Zhi Gao Liao ${ }^{\mathrm{a}}{ }^{*}$, Xiao Jing Zhao ${ }^{\mathrm{b}}$ and Ze Feng ${ }^{\mathrm{c}}$
}

Guangxi university of science and technology in China

aliaozhigao@126.com; bjinghuiwan@126.com; c474014299@qq.com

\section{Keywords: Supply chain finance; Accounts receivable financing; Game; Nash equilibrium.}

\begin{abstract}
Supply Chain Finance (SCF) evaluate the enterprise financing credit risk from the perspective of supply chain, and then solve the financing problem of small and medium enterprises. In this paper, through the establishment of game model, games of perfect information and two parties for accounts receivable financing mode were analyzed, and enable it to achieve the Nash equilibrium. Through the analysis: strengthening the punishment on all kinds of breach can help to reduce the credit risk and enhance the financing of enterprise credit.
\end{abstract}

\section{Introduction}

The small and medium enterprises play more and more important role in the China twenty-first Century economy. However, compared with large enterprises, it faces a variety of constraints, and the financing constraint is considered one of the most important constraints. The special situation of our country is having a relatively abundant labor, but capital is relatively scarce.This special economy structure makes it become a energetic part of the national economy in a very long period of time. However, in the process of financing for these small and medium enterprises, high risk, no abundant cash and other problems lead to a lot of large financial institutions are more inclined to large enterprises.

In order to solve the financing difficulty of small and medium enterprises, a new financial innovative financing model called supply chain finance becomes the most popular topic in recent years. The supply chain finance refers to credit bundled to the core enterprises as well as such risk prevention methods and technology as control of goods or credit ownership of financed enterprises.

Foreign scholars have different analysis on supply chain finance.Allen N Berger (2004) and Gregory F. Udell first put forward some new framework, ideas and the preliminary idea of supply chain finance on the financing of small and medium enterprises. Gonzalo Guillen (2006) proposed a reasonable model of supply chain management. It can influence the operation of enterprises and financing and increase the overall income. William Atkinson(2008) think that supply chain finance is the product of the financial sector and the real industry.Demica (2009) pointed out that investigators as many as $75 \%$ of 40 European top banks think that supply chain finance will continue to maintain a strong momentum of development. F.John Mathis and Joseph Cavinato (2010) found that many companies are increasingly looking to explore the best practices for managing global supply chain financing by research. Hofmann(2011) analyses supply chain finance's participants from the macro and micro level.

The exploration of Chinese scholars in the field is relatively late. Zhang Jialiang (2004) discusses the legal problems about the accounts receivable pledge involved. It belongs to the contract creditor's rights and using it as a pledge loan guarantee is permitted by law. Chen Xiangfeng, Shi Dailun, Zhu Daoli $(2005,2006)$ conducted a exploration on Financing storehouse and logistics finance. Yu Jianmei (2011) pointed out the financing models of supply chain finance is divided into four categories on the basis of others' research, including accounts receivable financing, confirming warehouse financing, financing warehouse financing and financing agency supervision.

Based on the above analysis, this paper analyzes the supply chain finance accounts receivable financing model and clear reveals the characteristics and the mechanism of financing by using game theory tobuild game model. 


\section{Accounts Receivable Financing Mode Of Supply Chain Finance}

Accounts receivable financing is on the basis of the supply chain, introducing core enterprises whic $\mathrm{h}$ have relationship with small and medium enterprises. Small and medium enterprises get the loan $\mathrm{f}$ rom commercial bank financing by the accounts receivableas a pledge.

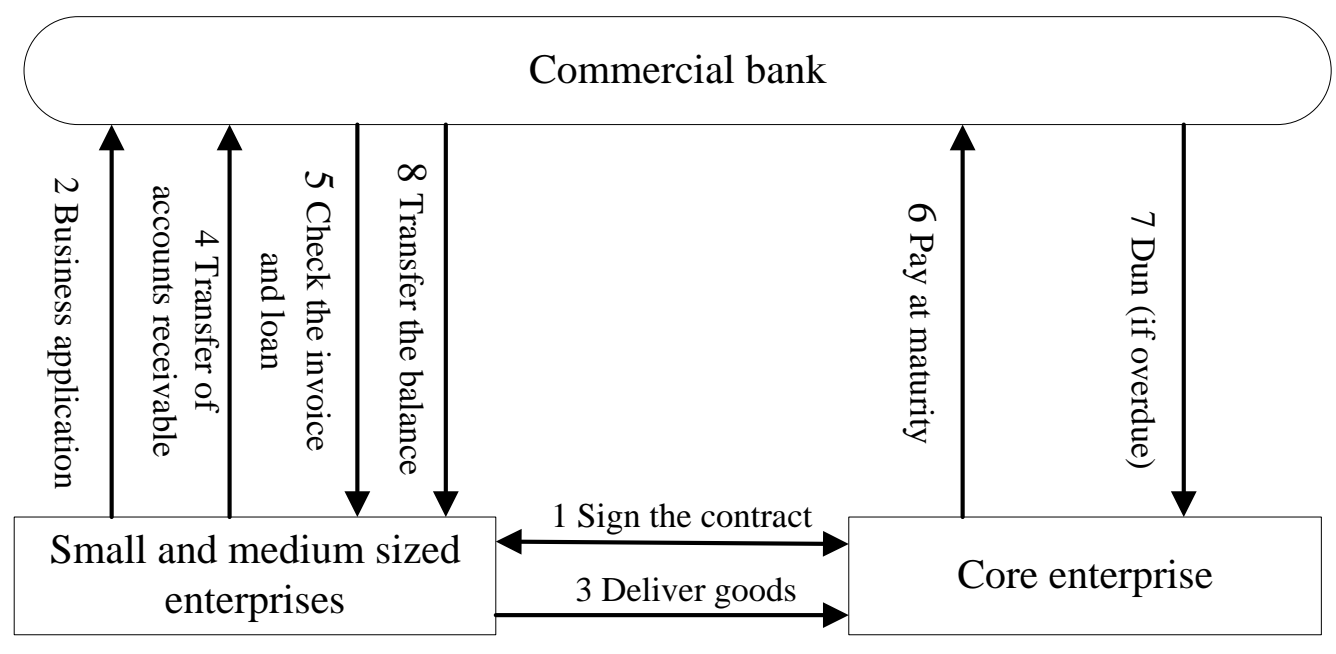

Figure 1. accounts receivable financing mode

Core enterprise, on the one hand, provides loan guarantees for small and medium enterprises. On the other hand, the core enterprise can mix the whole supply chain together through the flow of funds, which can benefit all the enterprises on the chain.

\section{The Establishment Of The Model}

Assumption. (1) The model has 3 main bodies, including small and medium enterprises, core enterprises and banks. Their actions are independent of each other.

(2) In the whole supply chain, the core enterprise is willing to guarantee service for small and medium-sized enterprises. Under this premise, bank lend to small and medium enterprises, otherwise it will not produce financing.

(3) Small and medium enterprises choose one-time loan and repay the loan.

\section{Symbols Definition}

$L$-Accounts receivable amount of the small and medium-sized enterprises.

$n$-Repayment years of the small and medium-sized enterprises.

$r_{0}$-Lending rate.

$r$-Deposit rates, we assume $r_{1} \succ r$.

$r_{1}$-Lending rates percent a year.

$r_{2}$-The yield of small and medium-sized enterprise loan for production.

$n_{0}$-This year could not afford to repay loans, assuming $n_{0}(\leq n)$.

$P_{1}$-Probability of repayment for small and medium enterprises.

$P_{2}$-Probability of repayment for core enterprises.

$C$-The cost of banks' supervision.

$F$-The banks' service profit.

$m$-The yield of core enterprises using unpaid accounts receivable funds.

$B$-The loss of small and medium enterprises if it does not pay the loan.

$N$-The loss of core enterprises if it does not pay the debt. 
Payoff Matrix. Through the above analysis, we can calculate the income shown in table 1 as follow.

Table 1 The payoff matrix

\begin{tabular}{|c|c|c|c|}
\hline \multirow[t]{2}{*}{ Bank } & & \multicolumn{2}{|c|}{ Small and medium enterprises } \\
\hline & & Repayment & No repayment \\
\hline \multirow[t]{6}{*}{$\begin{array}{c}\text { Core } \\
\text { enterprises }\end{array}$} & & $L r_{0}\left(r_{2}-r_{1}\right)-L\left(1-r_{0}\right)$ & $\frac{L r_{0}}{n} n_{0}\left(r_{2}-r_{1}\right)+\frac{L r_{0}}{n}\left(n-n_{0}\right)-B$ \\
\hline & $\begin{array}{l}\text { Repay } \\
\text {-ment }\end{array}$ & $L r_{0}\left(r_{1}-r\right)+F-C$ & $\frac{L r_{0}}{n} n_{0}\left(r_{1}-r\right)+F-C$ \\
\hline & & $L(m-1) n$ & $L m n-L$ \\
\hline & & $L r_{0}\left(r_{2}-r_{1}\right)-L\left(1-r_{0}\right)-L$ & $L r_{0}+\frac{L r_{0}}{n} n_{0}\left(r_{2}-r_{1}\right)-B-L$ \\
\hline & $\begin{array}{c}\text { No } \\
\text { repay- } \\
\text { ment }\end{array}$ & $\frac{L r_{0}}{n} n_{0}\left(r_{1}-r\right)-C$ & $-L r_{0}(1+r)-C$ \\
\hline & & $L(m+1) n-N$ & $L(m+1) n-N$ \\
\hline
\end{tabular}

(Note: the small and medium enterprise, bank, core enterprise from top to down in sequence)

\section{Game Analyses}

Game Of Perfect Information. For the model above, assuming a variety of punishment is 0 . The repayment of small and medium enterprises benefit more than no repayment, if the core enterprises choose repayment or not. So small and medium enterprises don't choose repayment. The repayment of core enterprises benefit more than no repayment, if small and medium enterprises the choose repayment or not. So core enterprises don't choose repayment. Because the banks know that the small and medium enterprises and the core enterprises will all choose no repayment, it will not lend to small and medium enterprises, achieving Nash equilibrium (not loans, no repayment, no repayment).

Because of the risk guarantee of core enterprises, the small and medium enterprises and the core enterprises will choose repayment if they have enough ability.

When the small and medium enterprises choose repayment,

$$
L(m-1) n-[L(m+1) n-N]=N-2 L n,
$$

If $N$ is enough large, assuming $N-2 \operatorname{Ln} \succ 0$, the core enterprises in this case will choose repayment in this case.

When the small and medium enterprises don't choose repayment,

$$
L m n-L-[L(m+1) n-N]=N+L n-L,
$$

If $N$ is large enough, assuming $N+L n-L \succ 0$, the core enterprises in this case will also choose repayment in this case.

We can see that, whether the small and medium enterprises repayment or not, core enterprises will choose repayment. Similarly, if B is large enough, medium and small enterprises will choose repayment. At the same time, it will reach Pareto optimal (loans, repayment, repayment).

Game Of Two Parties. Enterprises have the intention of repayment to a great extent, but because of the uncertain of whole supply chain, it is possible that enterprises break promise.

We can judge the benefits of banks by the research on games of the small and medium enterprises and core enterprises. Then we determine whether to loan.

The model has 2 main bodies, including small and medium enterprises and core enterprises. Portfolio strategy is as follows: (repayment, repayment), (no repayment, repayment), (no repayment, 
repayment), (no repayment, repayment). Probabilities of them appear as $P_{1} P_{2}, P_{1}\left(1-P_{2}\right),\left(1-P_{1}\right) P_{2},\left(1-P_{1}\right)\left(1-P_{2}\right)$.The relationship between them show as fig2 below.

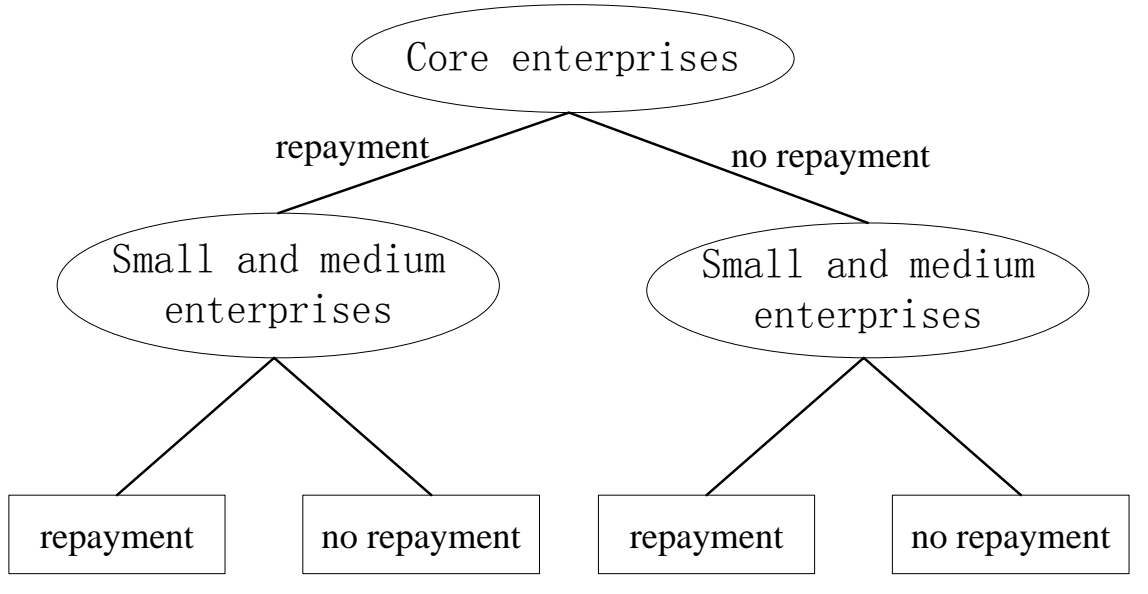

Figure 1. game of two parties

The benefit of bank called $E$ is

$$
\begin{aligned}
& E(\text { loans })=P_{1} P_{2}\left[L r_{0}\left(r_{1}-r\right)+F-C\right]+P_{1}\left(1-P_{2}\right)\left[\frac{L r_{0}}{n} n_{0}\left(r_{1}-r\right)-C\right]+ \\
& \left(1-P_{1}\right) P_{2}\left[\frac{L r_{0}}{n} n_{0}\left(r_{1}-r\right)+F-C\right]+\left(1-P_{1}\right)\left(1-P_{2}\right)\left[-L r_{0}(1+r)-C\right] \\
& =P_{1} P_{2} L r_{0}\left(\frac{2 n_{0}}{n} r-\frac{2 n_{0}}{n} r_{1}-2 r+r_{1}-1\right)+P_{1} L r_{0}\left(\frac{n_{0}}{n} r_{1}-\frac{n_{0}}{n} r+r+1\right) \\
& +P_{2}\left[L r_{0}\left(\frac{n_{0}}{n} r_{1}-\frac{n_{0}}{n} r+r+1\right)+F\right]-L r_{0}(1+r)-C
\end{aligned}
$$

When we make

$$
\begin{aligned}
& P_{1} P_{2} L r_{0}\left(\frac{2 n_{0}}{n} r-\frac{2 n_{0}}{n} r_{1}-2 r+r_{1}-1\right)+P_{1} L r_{0}\left(\frac{n_{0}}{n} r_{1}-\frac{n_{0}}{n} r+r+1\right)+ \\
& P_{2}\left[\operatorname{Lr} r_{0}\left(\frac{n_{0}}{n} r_{1}-\frac{n_{0}}{n} r+r+1\right)+F\right] \succ L r_{0}(1+r)+C
\end{aligned},
$$

banks will choose loan. Then it achieves Nash equilibrium (loans, repayment, repayment). In addition, the repayment probabilities of enterprises become variables, reducing the credit requirements for small and medium enterprises and making benefits all the enterprises in long term.

\section{Conclusions}

We can draw the following conclusions through the analysis above. First, building a more perfect information feedback system is especially important for supply chain finance. The flow of information between the main body participated is maintained by the perfect information feedback system. This can enhance the effectiveness of the core enterprises and banks' supervisions and can effectively reduce the cost of the core enterprises and banks' supervision. Secondly, it is significant to strengthen the penalties of various default behaviors. Because the credit system of our country is still not perfect enough and default penalty measures are also not clear, it poses a great threat to the development of supply chain finance. So, clearing default punishment measures and strengthening the construction of credit system are of great significance to reduce credit risks and enhance 
financing enterprise credit. Finally, banks must choose carefully the industry with a bank loan. In different industries, supply chain system on the stability of their cooperation is bigger difference.

\section{Acknowledgments}

This work was financially supported by philosophy and social fund of Guangxi (13BGL009)and the project of outstanding young teachers' training in higher education institutions of Guangxi.

\section{References}

[1]Allen N. Berger, Gregory F. Udell. A More Complete Concep-tual Framework for SME Finance. World Bank Conference on Small and Medium Enterprises: Overcoming Growth Constraints, 2004, (10): 14-15.

[2]Gonzalo Guillen, Mariana Badell. A Holistic Framework for Short-term Supply Chain Management Integrating Production and Corporate Financial Planning. Production Economics, 2006, (7): 25-27.

[3]William Atkinson. Supply Chain Finance: The Next Big Opportunity [J], SupplyChain Management Review, 2008(4):57-60

[4]Demica.Supply Chain Finance:Strengthening the Links[R].Demica Report Series,2009(10):4.

[5]F. John Mathis, Joseph Cavinato.2010.Financing the Global Supply Chain: Growing Need for Management Action [J].

[6]Erik Hofmann and Oliver Belin.Supply Chain Finance Solutions:Relevance-Propositions-Market Value[J].New York:Hei-delberg,2011.

[7] J.L. Zhang. Bank for chattel mortgage loan business risk prevention, Southwest of Financial, 2004(6):37-37

[8] X.F.Cheng, D.L.Shi and D.L Zhu. Finance-transportation and logistics financial service innovation [J]. Tech Review, 2005, (9):30-33.

[9] X.F. Cheng, D.L. Shi and D.L. Zhu.The financial supply chain and financing storehouse services [J]. Logistics Technology and Application, 2006, (3):93-95.

[10] J.M. Yu. Using financial supply chain to ease the small and medium-sized enterprise financing difficult problem [J]. Economic Aspect, 2011, (3):99-102. 